\title{
PROPOSTA DE UTILIZAÇÃO DE PONTEIRAS DRENANTES PARA REDUÇÃO DA UMIDADE EM FRENTES DE LAVRA - UM ESTUDO DE CASO DA MINA DO BARREIRO - ARAXÁ MG
}

\author{
Vitor Magalhães Maciel ${ }^{1}$; Luiz Gustavo Moraes de Macedo ${ }^{2}$; Marcus Vinicios Andrade \\ $\mathrm{Silva}^{3}$; Michelle Cintra Abud Mariano ${ }^{4}$; Ramon Vinhas Oliveira Lima ${ }^{5}$; Rodrigo Arthur Prestes \\ Law $^{6}$; Roberto Giacomini Horii ${ }^{6}$
}

\section{RESUMO}

As minas a céu aberto que já atingiram o nível de água subterrânea ou possuem frentes de lavra com excesso de umidade, em especial as que lavram espessos mantos de intemperismo a exemplo das minas de rochas fosfáticas, nem sempre apresentam um resultado homogêneo do rebaixamento de nível de água por meio das técnicas convencionais (canaletas, drenos horizontais profundos, poços, SUMP's, etc.) em função da heterogeneidade geológica que torna o ambiente extremamente heterogêneo e anisotrópico do ponto de vista hidrogeológico. Além da própria água, que pode se tornar um enorme transtorno operacional para a lavra, existe ainda a questão da umidade dos taludes, que além de aumentar a instabilidade geotécnica e limitar o ângulo de talude reduzindo o volume de minério lavrável, gera enormes desafios ao longo do processamento mineral desde a britagem até a moagem do mesmo. Com o objetivo de reduzir a umidade em frentes de lavra com maior rapidez e menores custos, foi testado o método das ponteiras drenantes em uma das frentes de lavra da Mina do Barreiro, método este que se mostrou bastante promissor e com ganhos consideráveis na redução da umidade.

\footnotetext{
ABSTRACT

${ }^{1}$ Vale Fertilizantes: Av. Arafértil, 5000 - CEP: 38184-270 - Araxá-MG; (34)3669-6388; fax: (34) 3669-6300; vitor.maciel@ valefert.com.

${ }^{2}$ Vale Fertilizantes: Rodovia MG 341, Km 25 - CEP: 38185-000 - Tapira-MG; (34)3669-5411; fax: (34) 3669-6300; luiz.macedo@ valefert.com.

${ }^{3}$ Vale Fertilizantes: Av. Arafértil, 5000 - CEP: 38184-270 - Araxá-MG; (34)3669-6231 fax: (34) 3669-6300; marcus.andrade@ valefert.com

${ }^{4}$ Vale Fertilizantes: Av. Arafértil, 5000 - CEP: 38184-270 - Araxá-MG; (34)3669-6317; fax: (34) 3669-6300; michelle.abud@ valefert.com.

${ }^{5}$ Instituto Passo 1: Av. Fernando Vilela, 2030 - CEP: 38400-456 - Uberlândia-MG, (34)3221-4300; ramon.vinhas@ gmail.com

${ }^{6}$ Itubombas. Av. Caetano Rugieri, 5170-A Pq. das Indústrias - CEP 13309-710 - Itu-SP , (11) 4013-1116; fax: (11) 4022-5785; contato@itubombas.com.br.
} 
The open pit mines that have reached the groundwater level or have mining fronts with excess moisture, especially those who plow thick mantles of weathering the example of mines phosphate rock, do not always have a homogeneous result of drawdown water by conventional techniques (channels, deep horizontal drains, wells, sumps, etc.) depending on the geological heterogeneity becomes extremely heterogeneous and anisotropic hydrogeological environment point of view. In addition to the water itself, which can become a huge operational inconvenience for the mining, there is still the question of humidity of slopes, which besides increasing the geotechnical instability and limit the slope angle of reducing the volume of mineable ore, creates huge challenges during the mineral processing from crushing to grinding the same. In order to reduce the moisture in mining fronts faster and lower costs, it has been tested the method of draining ferrules in one of the mining fronts Mine Barreiro, which method proved quite promising and with considerable gains in reducing humidity.

Palavras-Chave - Ponteiras drenantes. Rebaixamento. Mineração.

\section{INTRODUÇÃO}

O Complexo Carbonatítico do Barreiro está localizado nas coordenadas geográficas $19^{\circ} 38^{\prime}$ sul, $46^{\circ} 56^{\prime}$ oeste, aproximadamente $6 \mathrm{~km}$ ao sul da cidade de Araxá, estado de Minas Gerais. O Barreiro é um dos mais importantes Complexos Alcalinos Carbonatíticos em termos econômicos que ocorrem em Minas Gerais e Goiás. Estes Complexos alinham-se ao longo de falhas com direção NW, nas quais ocorreu a intrusão dos corpos alcalino-carbonatíticos e kimberlíticos durante o evento magmático que ocorreu na plataforma brasileira do fim do Jurássico ao Terciário inferior (Biondi, 2003). O Complexo Carbonatítico de Araxá tem forma circular com cerca de $5 \mathrm{~km}$ de diâmetro (Figura 1) e está encaixado em quartzitos e xistos pré-existentes (SILVA et al., 1979). 


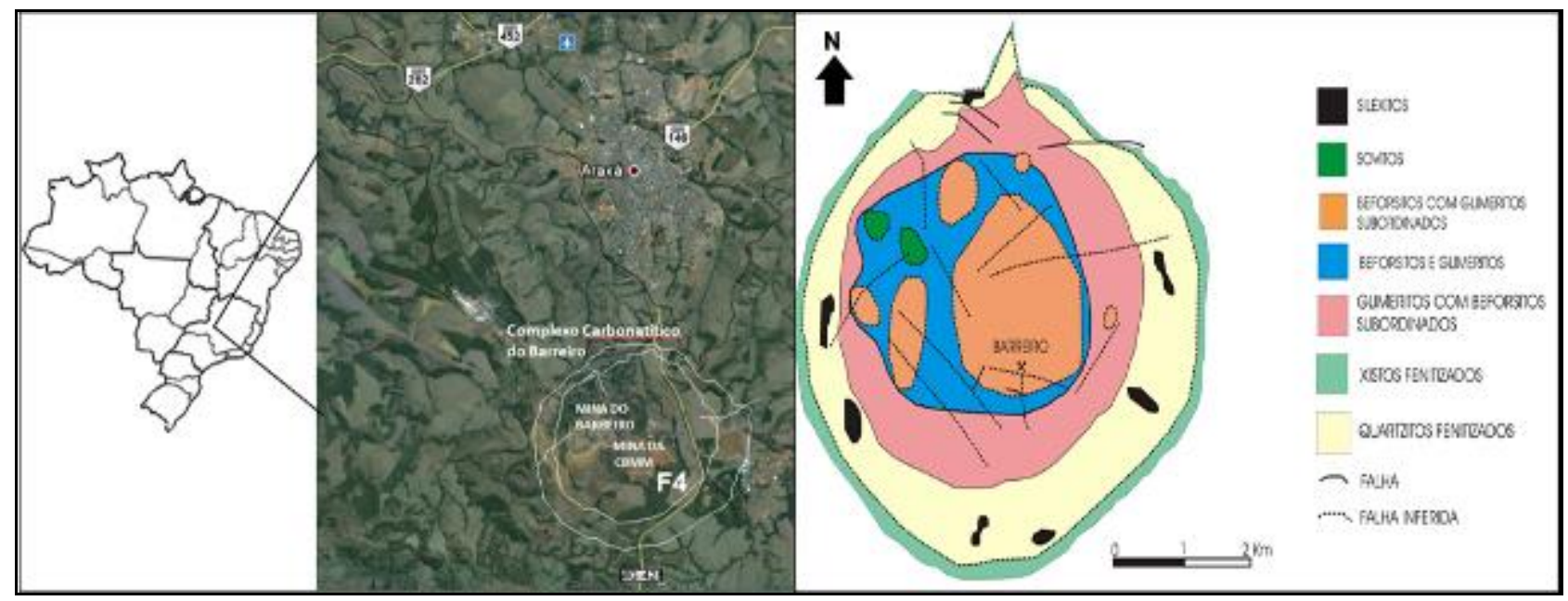

Figura 1 - Localização e geologia regional da área de estudo (SILVA et al., 1979).

Para viabilizar as operações mineiras (desenvolvimento da mina, lavra e transporte do minério e do estéril) é necessário rebaixar o nível de água subterrânea na área da mina de modo a evitar a formação de áreas alagadas, reduzir de umidade nos taludes, elevar seu coeficiente geotécnico de segurança, e até mesmo impedir a inundação de trechos mais profundos da área a ser lavrada. Porém devido à heterogeneidade geológica das minas de fosfato, o que torna a compartimentação hidrogeológica extremamente complexa, nem sempre é possível criar e manter um sistema de rebaixamento de nível de água subterrânea que garanta a operacionalização econômica de todas as frentes de lavra, neste contexto, a proposta de utilização do método de ponteiras drenantes, muito utilizada na construção civil, pode ser útil para frentes de lavra específicas que necessitem de uma redução rápida da umidade.

O projeto de teste das ponteiras drenantes na região denominada morro da oficina, contemplou em seu primeiro cenário, a execução de 140 ponteiras com espaçamento de 2 metros, a fim de rebaixar o nível da água local no talude 1010. A Figura 2 representa a interceptação do nível de água, com a topografia da mina. 


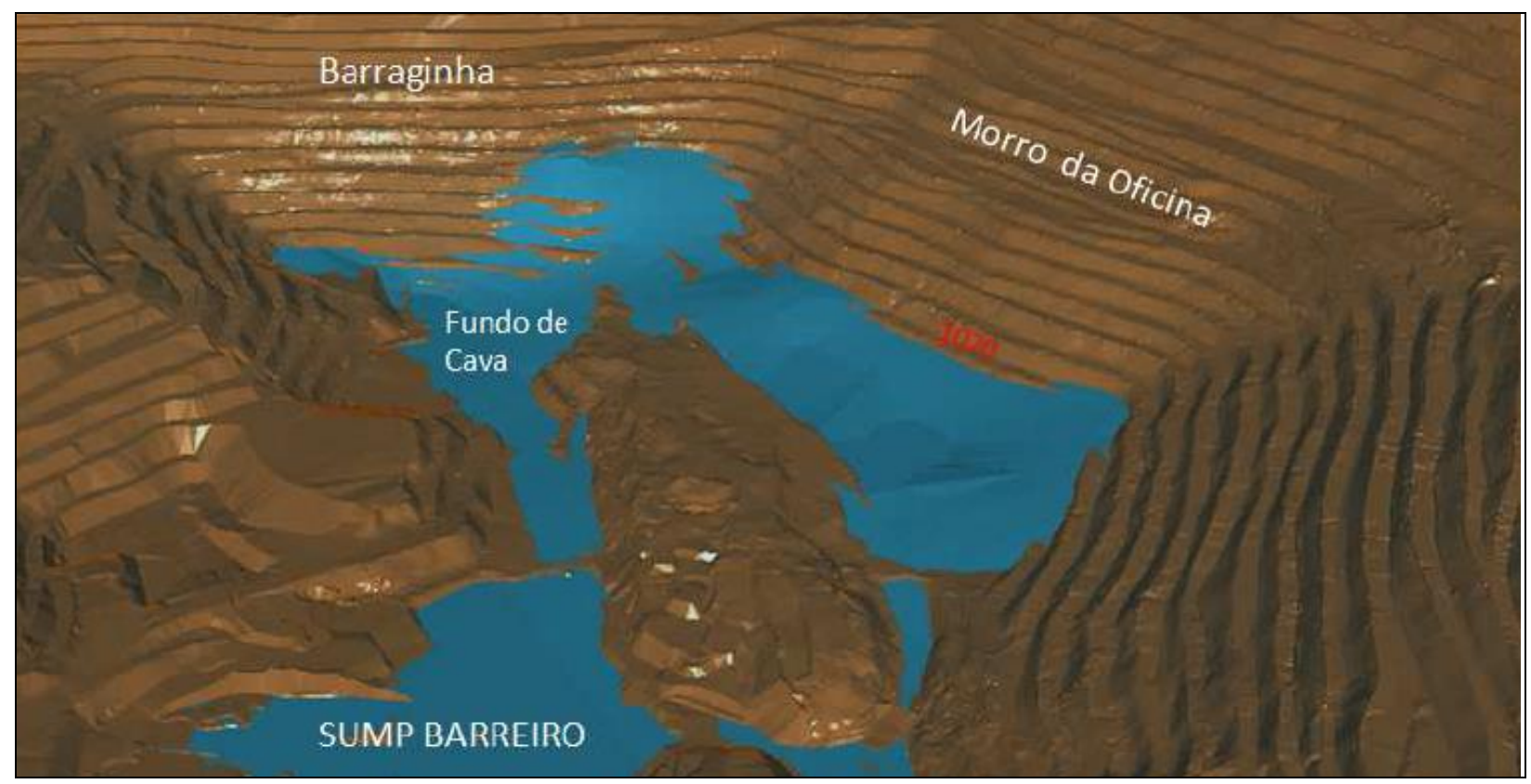

Figura 2: Superfície do nível de água interceptando a topografia atual da Mina do Barreiro (Fonte: Vale Fertilizantes).

\section{OBJETIVO}

Realizar teste do sistema de ponteiras drenantes para redução de umidade no banco 1010 na Mina do Barreiro, localizada no Complexo Mineroquímico de Araxá.

\subsection{Objetivos específicos}

- $\quad$ Promover redução local do nível da água (n.a.);

- Quantificar redução de umidade proporcionada pelo sistema;

- Verificar viabilidade do sistema na operação de mina.

\section{SISTEMA DE REBAIXAMENTO POR PONTEIRAS DRENANTES}

O sistema de rebaixamento consiste na disposição, da área a rebaixar e de um conjunto de tubo coletor (de aço ou PVC, geralmente com 4"), dotado de tomadas de água espaçadas geralmente com cerca de 1,5 metros, conforme mostrado na Figura 3. 


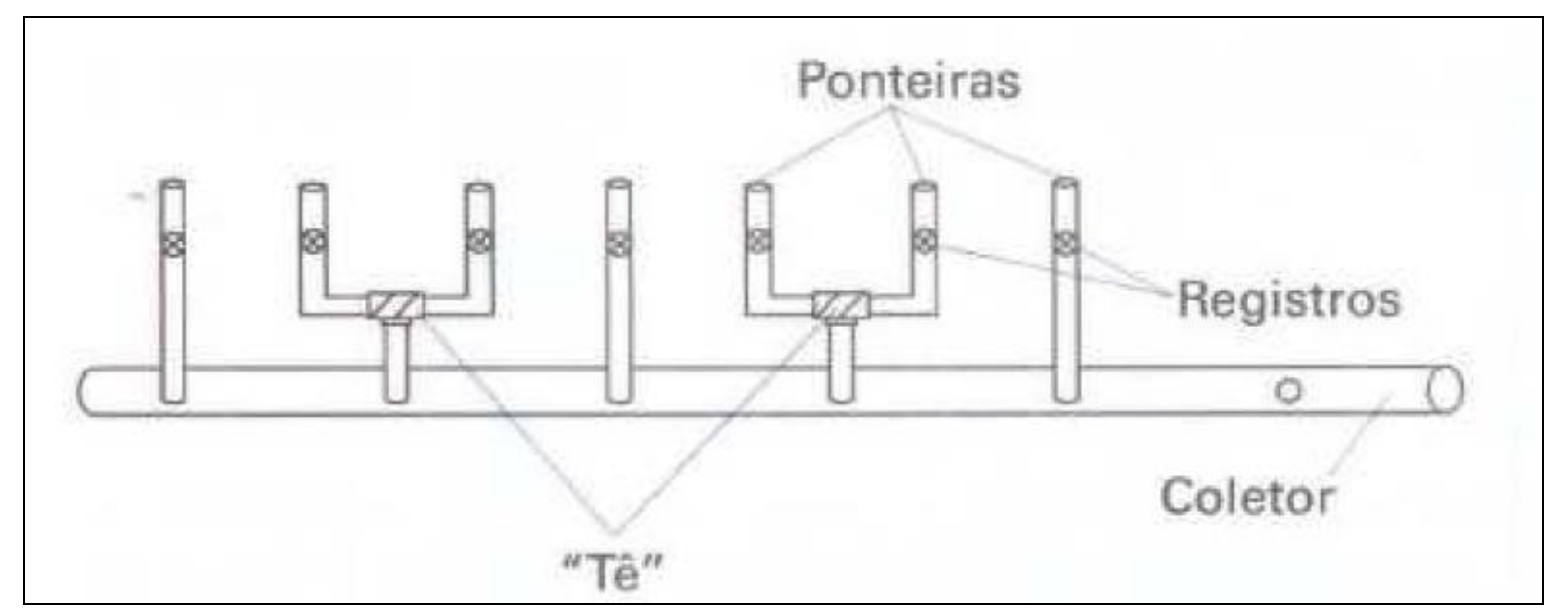

Figura 3: Detalhe para a disposição de ponteiras, conectados no tubo coletor (Fonte: Alonso, 1999).

Essas tomadas são furos feitos no tubo coletor, nos quais se instala luvas com diâmetro de $1 \frac{1}{2}$ ”, às quais se ligam as ponteiras drenantes, compostas na maioria das vezes por tubos de PVC perfurados na extremidade inferior e protegidos por geossintéticos ou por tubos com ranhuras. A ligação das ponteiras às luvas do tubo coletor é feita por meio de mangueiras plásticas (conectores), dotadas de um registro. Quando estão inoperantes, fecha-se o registro ou bloqueiam-se as tomadas com "tampões", para evitar a entrada de ar no sistema (Alonso, 2009).

A água extraída pelas ponteiras drenantes é conduzida pelo tubo coletor até a câmara de vácuo, de onde a bomba de recalque retira para o local apropriado. As ponteiras são instaladas no solo, próximas ao tubo coletor. Como a água é retirada do solo com a utilização de vácuo, todo o sistema (união entre os segmentos de tubo coletor, ligações da ponteira ao coletor e etc.) deve ser o mais estanque possível, para impedir a entrada de ar, que diminui a eficiência do rebaixamento. Além disso, constitui uma boa técnica evitar desníveis ao longo da linha do coletor, instalando o mesmo em um plano com ligeiro aclive no sentindo da câmara de vácuo, a fim de impedir a formação de bolsas de ar em seu interior.

A partir da elevação no número de juntas no tubo coletor, além das ligações das ponteiras a ele, percebe-se que não é possível obter o vácuo absoluto no sistema, pois sempre haverá entrada de ar. Por essa razão, embora na teoria a altura máxima de aspiração seja de 10,33 m de coluna de água (1 atm), na prática o rebaixamento conseguido é na ordem de 7 metros próximo da ponteira, que via, de regra, tem 8 metros de comprimento, já incluindo 1 metro da seção filtrante. Assim no centro da escavação o rebaixamento e na ordem de 7 metros. Quando se usa o processo de rebaixamento em escavações muito profundas, utilizam-se vários estágios de ponteiras, conforme e mostrado na Figura 4. 


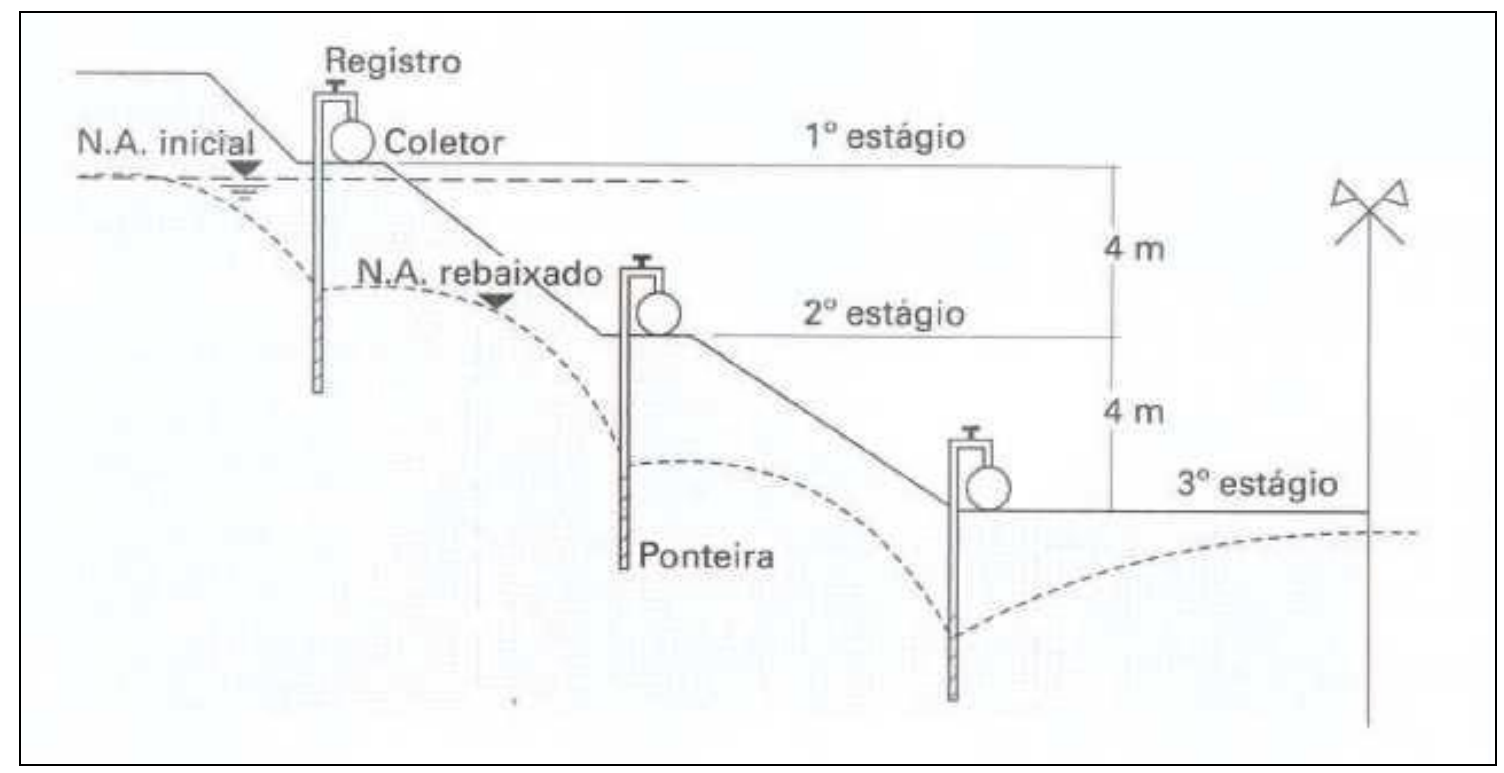

Figura 4: Exemplos de rebaixamento com três estágios de ponteiras (Fonte: Alonso, 1999).

A vazão d'água extraída do solo pelas ponteiras varia de acordo com sua permeabilidade, sendo normais vazões na faixa de $0,5 \mathrm{~m}^{3} / \mathrm{h}$ a $1,0 \mathrm{~m}^{3} / \mathrm{h}$.

Os conjuntos (bomba de vácuo, câmara de vácuo e bomba de recalque) de cada nível de ponteiras devem ser instalados no nível dos coletores para garantir maior eficiência da sucção, visto que o processo de rebaixamento é a vácuo (sucção máxima de 1 atm que é igual a 10,33 metros de coluna de água a nível do mar). Por essa razão, quanto mais se amparam os conjuntos em maiores profundidades, maior será a altura manométrica, portanto, em tese, as bombas de recalque deverão ser mais potentes.

\section{IMPLANTAÇÃO DO SISTEMA DE PONTEIRAS DRENANTES}

As ponteiras foram instaladas na bancada 1010, localizada no morro da oficina, local onde hoje está concentrada toda a atividade de lavra de minério e estéril na Mina do Barreiro. A Figura 5 representa as ponteiras inicialmente propostas. A motivação para este teste com as ponteiras drenantes é devido à necessidade de desenvolver técnicas que visem o rebaixamento do nível de água, para atender e viabilizar a operação de mina na região. 


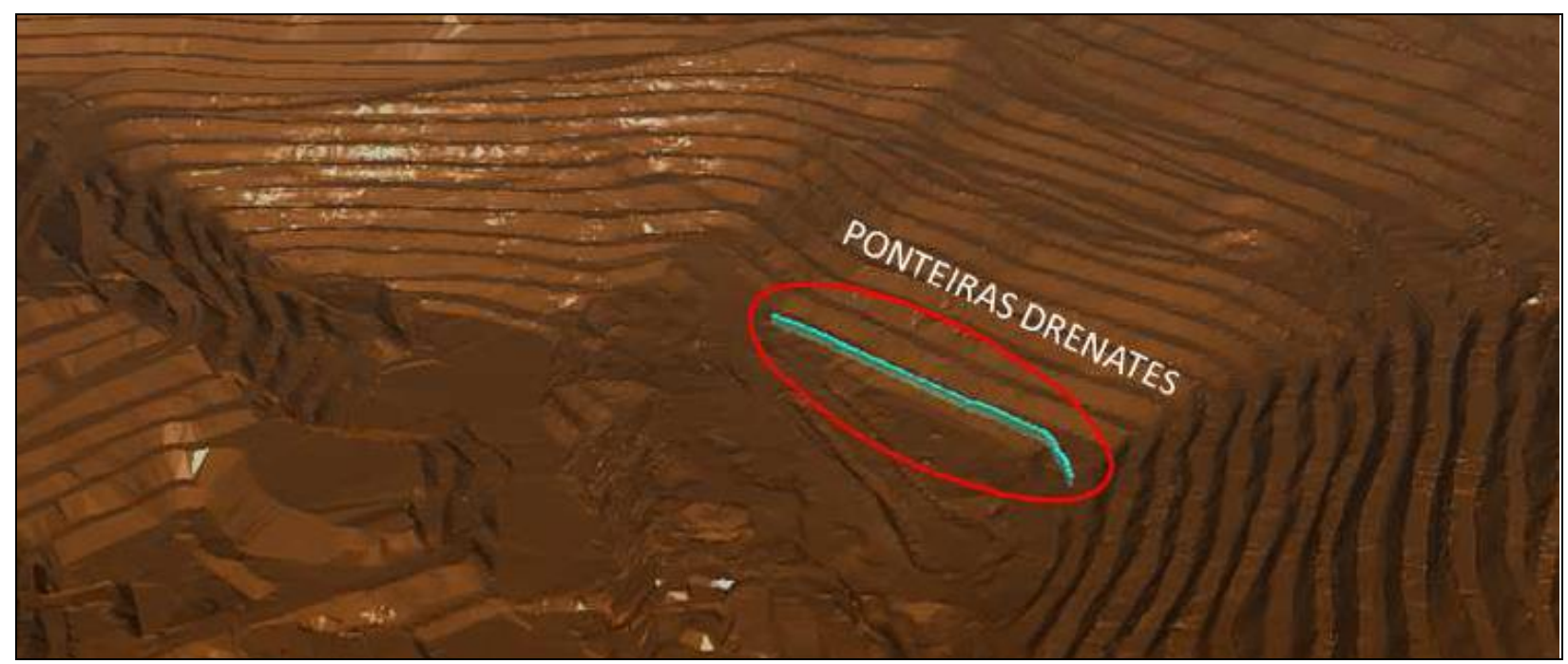

Figura 5: Localização das ponteiras na bancada 1010. Fonte: Vale Fertilizantes).

Por meio de uma ação conjunta entre as gerências de operação de mina e Hidrogeologia/Geotecnia, foi possível realizar as perfurações para a instalação das ponteiras da empresa Itubombas fazendo uso da estrutura de perfuração da própria equipe da mina (perfuratrizes, operadores, etc.). Inicialmente o teste contemplava a execução de 140 ponteiras de 9 metros de comprimento, instaladas a cada 2 metros, totalizando 280 metros de sistema. Com as dificuldades operacionais relacionados às características geológicas do material, foi possível a instalação de 79 ponteiras, com espaçamento variando entre 2 e 4 metros. Foram necessários dois dias de perfuração e instalação de todo o sistema. A configuração total foi finalizada com aproximadamente 214 metros. A Figura 6 mostra um croqui que representa a configuração final do sistema.

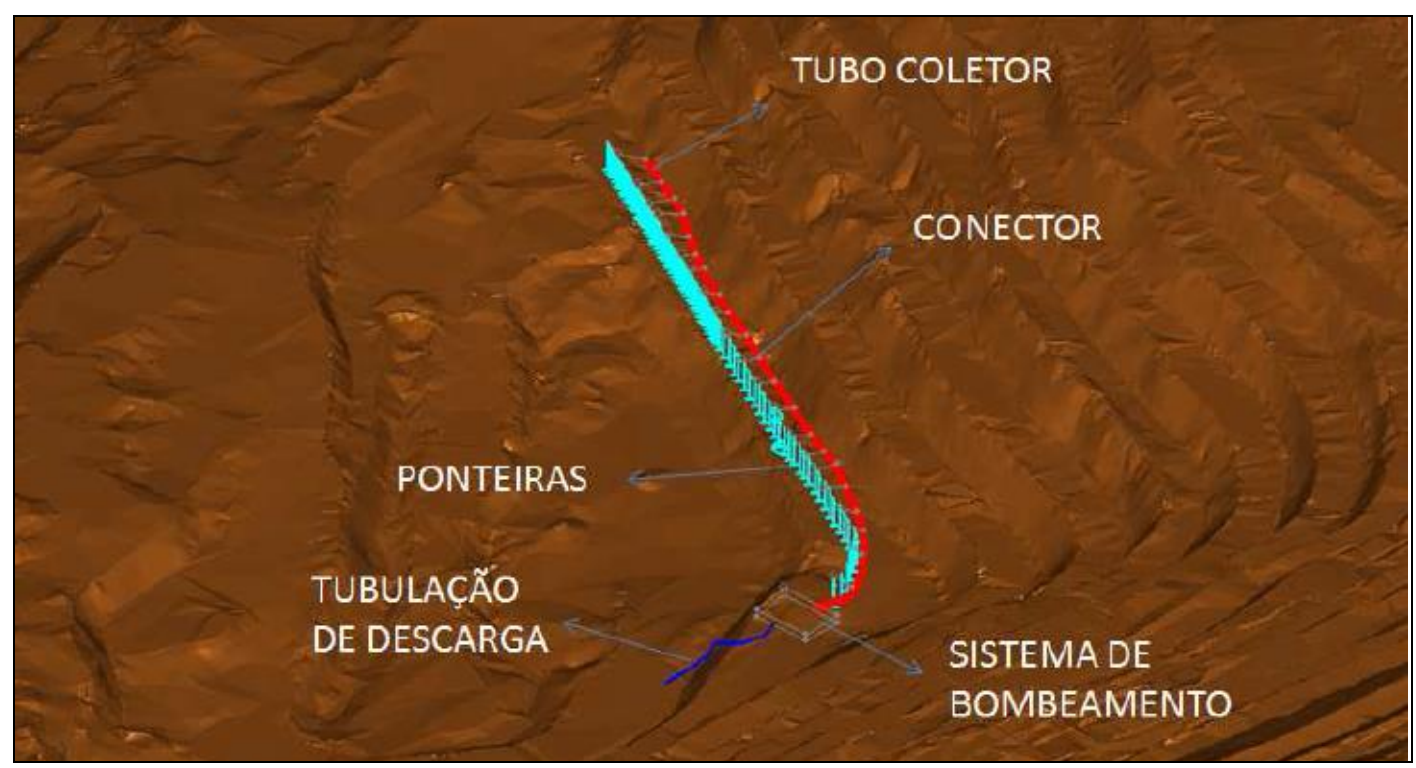

Figura 6: Croqui com a representação do sistema executado (Fonte: Vale Fertilizantes). 
Após a perfuração foram cravadas as ponteiras. Nem sempre foi possível a cravação total das ponteiras, visto que em algumas perfurações houve colapso da parede do furo durante e/ou após a retirada das ferramentas de perfuração.

\subsection{Ponteiras}

As ponteiras utilizadas constituem-se de tubos de PVC de 1 1/2”, ranhurados $0.4 \mathrm{~mm}$ com 1 metro de comprimento, configurando a ponteira propriamente dita, terminando com uma peça também de PVC (8 metros de comprimento). A Figura 7 mostra as ponteiras utilizadas no teste da Mina do Barreiro.

A instalação das ponteiras no solo é feita em perfurações prévias executadas com circulação d'água.

Para melhor eficiência e durabilidade das ponteiras recomenda-se que sejam envolvidas por tela de nylon, com malha de 0,6 mm, para evitar que a água, ao ser retirado do solo, carregue suas partículas sólidas, porém no teste não foi instalado.

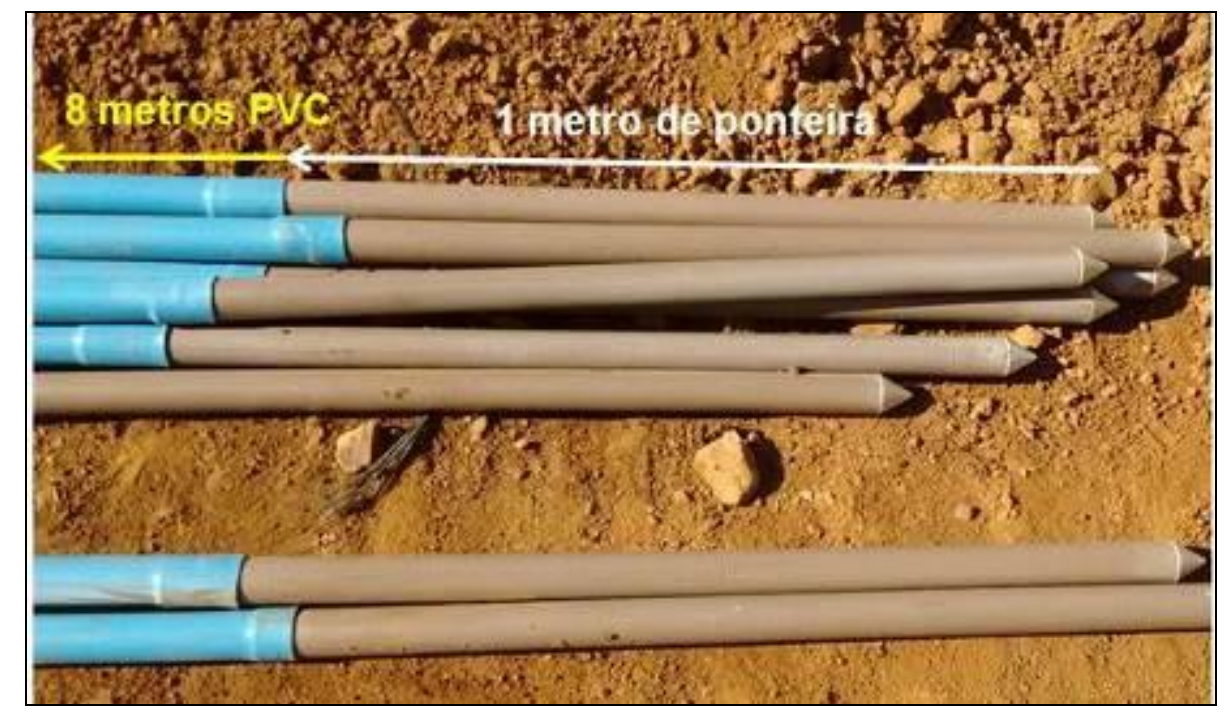

Figura 7: Ponteiras Itubombas utilizadas no teste na Mina do Barreiro (Fonte: Vale Fertilizantes).

\subsection{Conectores}

Os conectores são peças de plástico transparentes, que permitem a visualização da passagem de água entre as ponteiras e a tubulação coletora. São dotadas de uma válvula de registro que permite controlar a passagem de água e ar. A Figura 8 mostra a fotografia de um dos conectores usados no teste. 


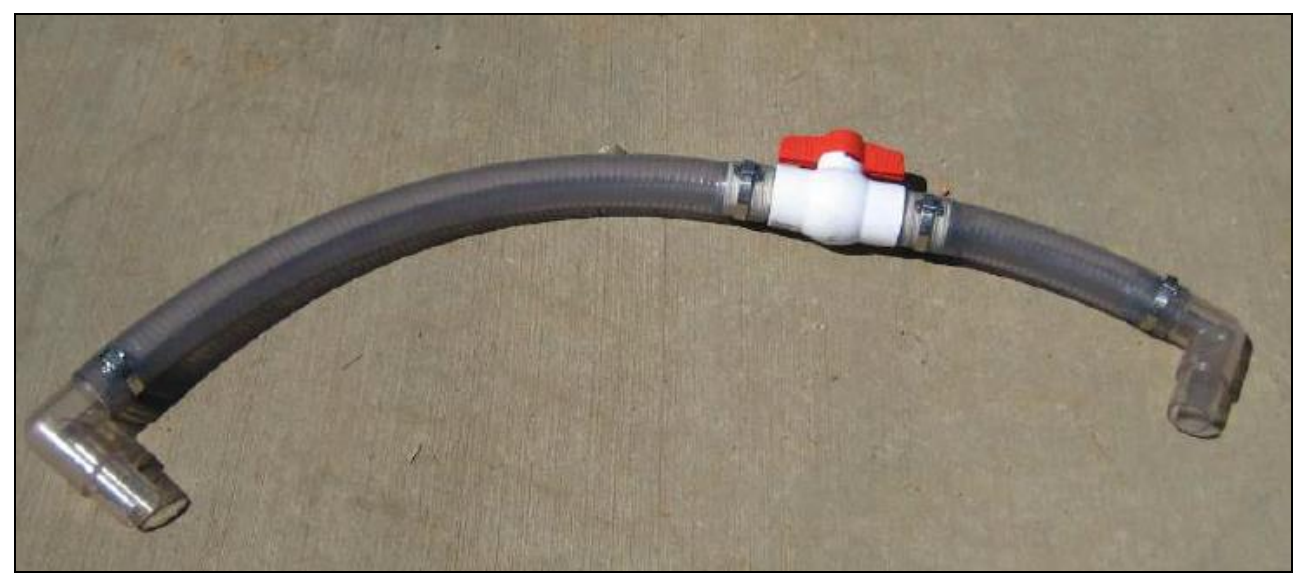

Figura 8: Conector transparente usado ligar a ponteira drenante à tubulação coletora (Fonte: Vale Fertilizantes).

\subsection{Sistema de bombeamento}

O conjunto de bombeamento (bomba de vácuo, câmara de vácuo e bomba de recalque), pertence à empresa Itubombas. Trata-se do modelo Motobomba a Diesel (ITU-44S10), com escorva contínua automática a vácuo, Run Dry, que permite a passagem de sólido de até $75 \mathrm{~mm}$.

Possui peso total bruto de $2.400 \mathrm{~kg}$. A potência do equipamento permite a instalação de até 140 ponteiras drenantes, com uma vazão de descarga de até $350 \mathrm{~m} 3 / \mathrm{h}$. A Figura 9 representa as informações gerais do equipamento utilizado.

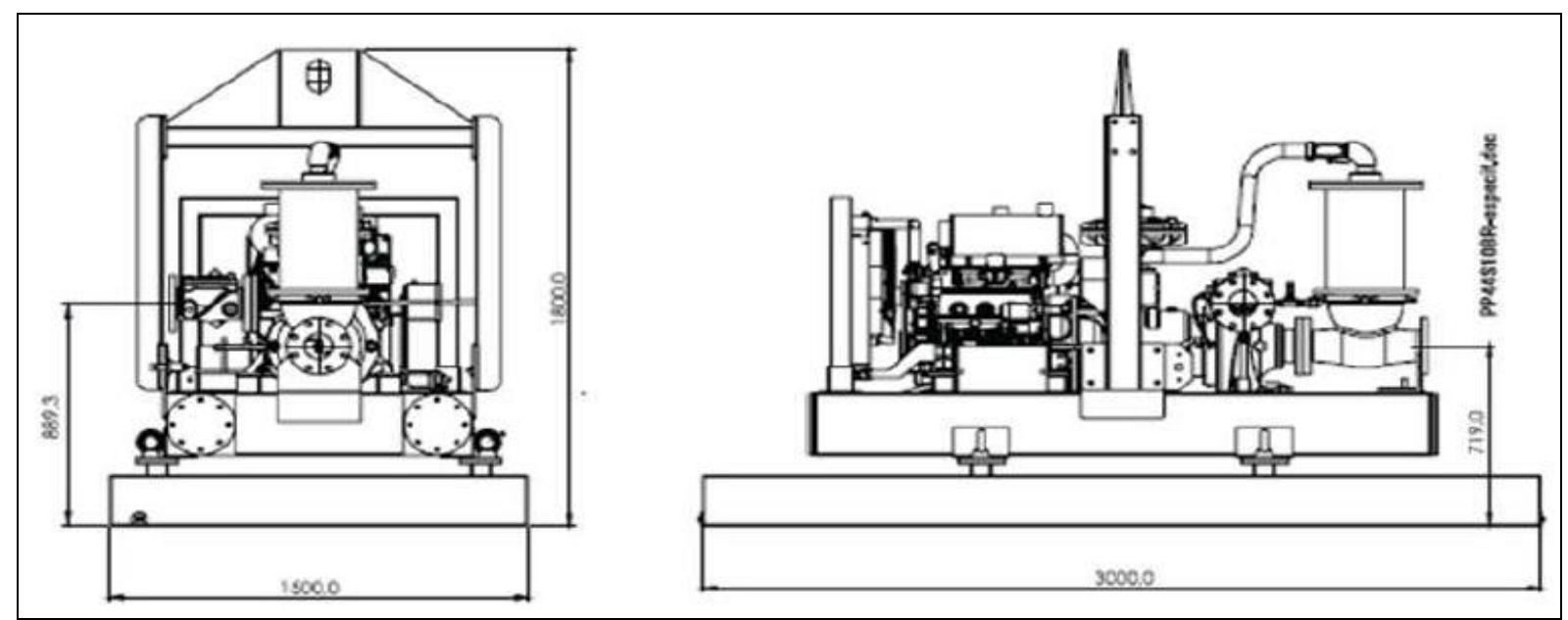

Figura 9: Sistema de bombeamento utilizado no teste (Fonte: Itubombas)

A Figura 10 apresenta o sistema em operação e a Figura 11 mostra a bomba de vácuo que esta conectada ao sistema. 


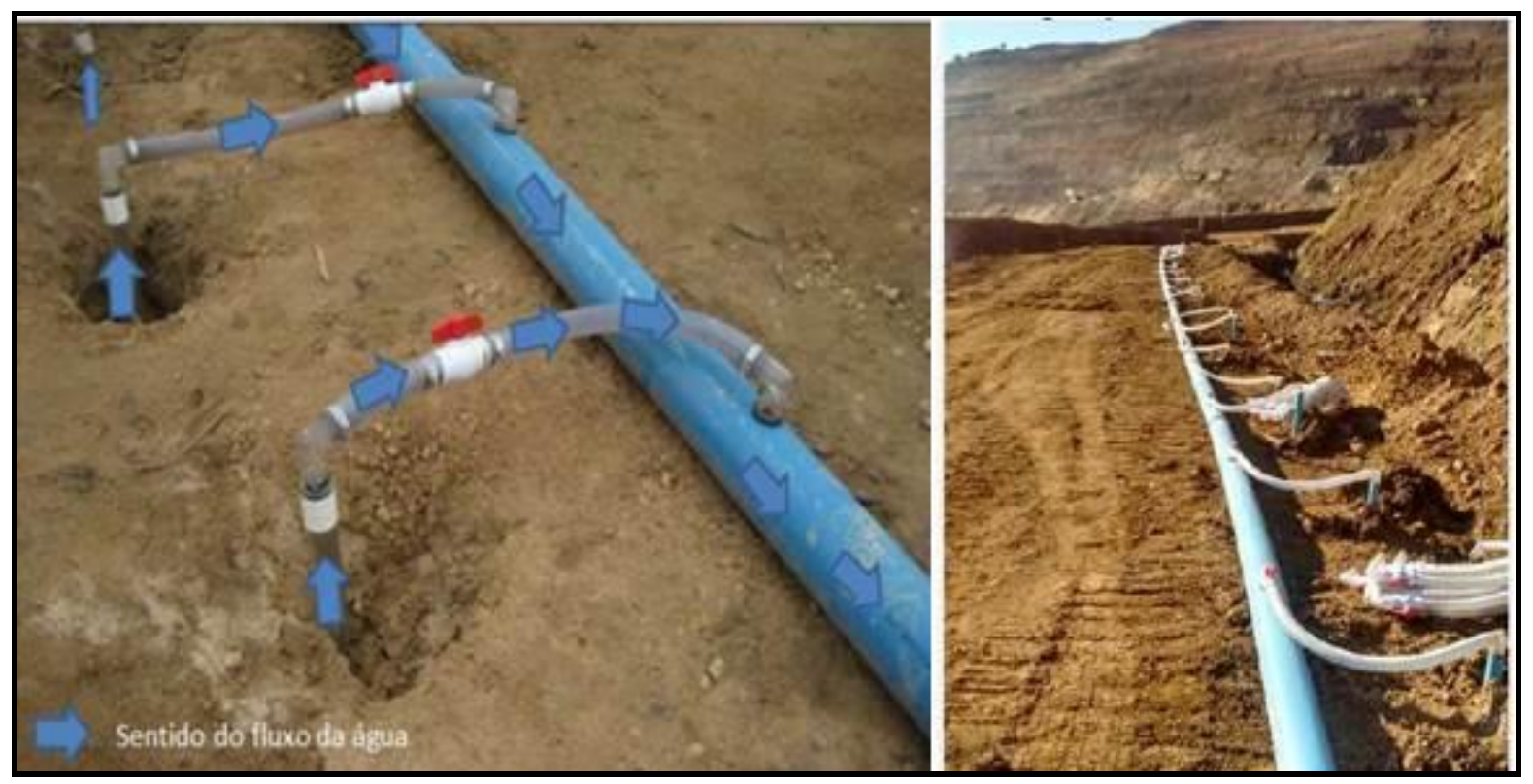

Figura 10: Sistema de ponteiras drenantes em operação (Fonte: Vale Fertilizantes).

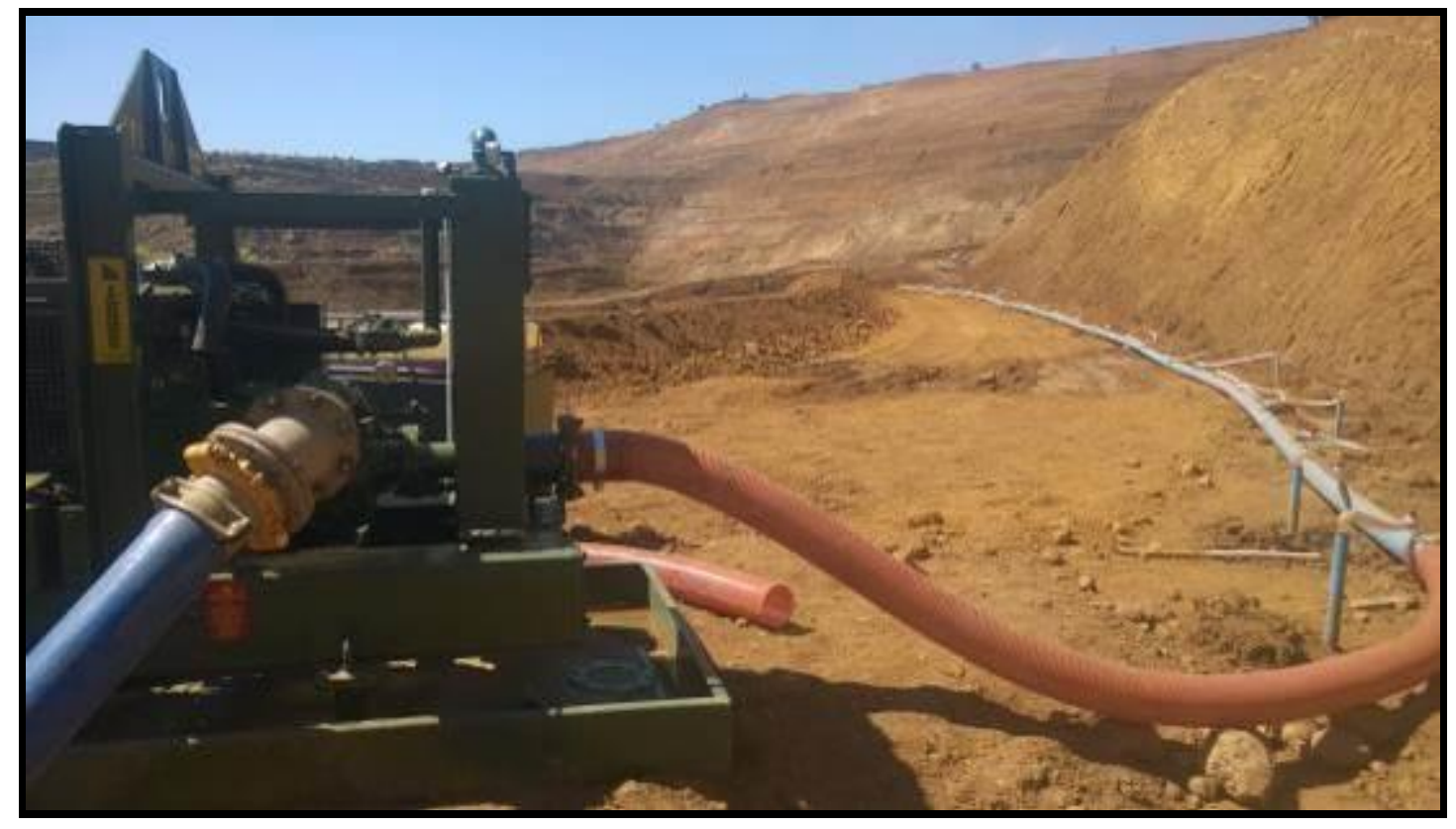

Figura 11: Vista da Bomba a vácuo e do sistema de ponteiras drenantes (Fonte: Vale Fertilizantes).

\section{TIPOLOGIA DO MINÉRIO}

As ponteiras interceptaram três diferentes tipologias de minério na bancada 1010, que são o oxidado, cimentado e o SIC B.

Vinte e três ponteiras atravessaram a tipologia denominado cimentado, seis ponteiras atravessaram a tipologia SIC-B e cinquenta ponteiras atravessaram a tipologia oxidado. A figura 12 
apresenta a disposição das ponteiras, ao longo das tipologias de minério. E a Figura 13 mostra as ponteiras que obtiveram os melhores rendimentos de vazão no teste.

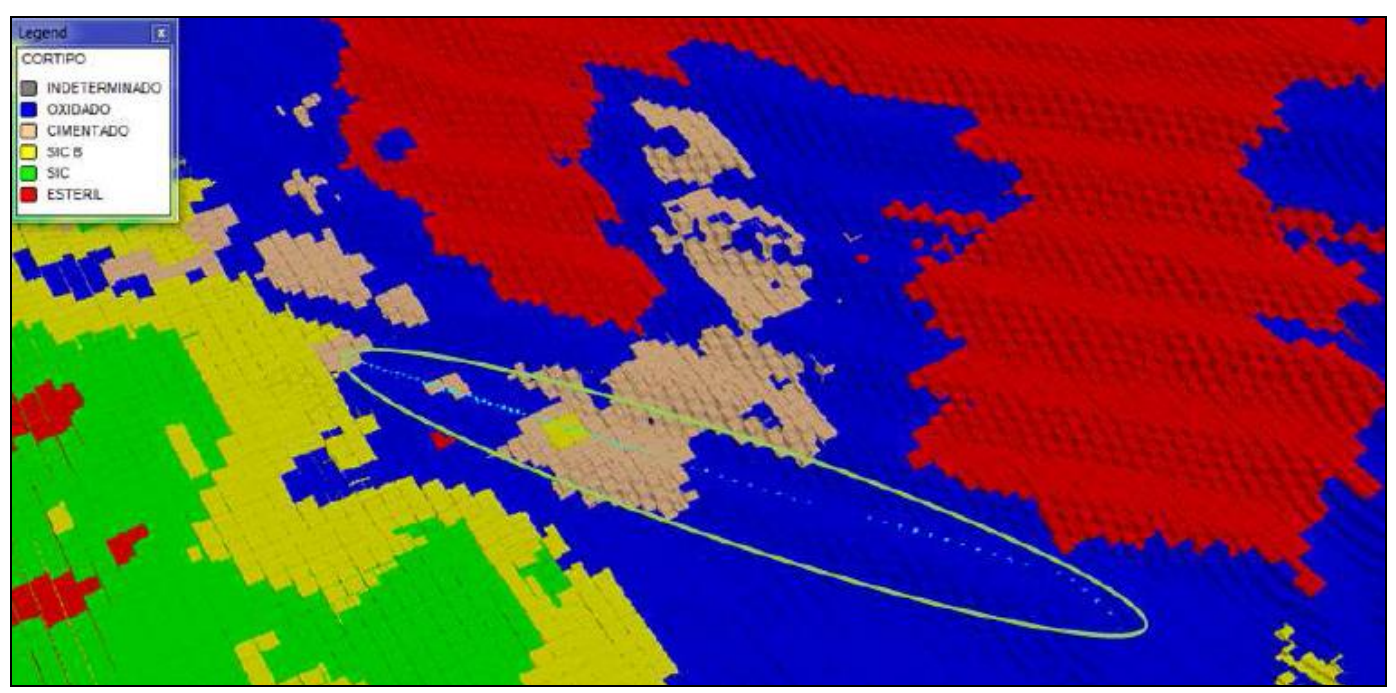

Figura 12: Localização das ponteiras em relação à tipologia de minério (Fonte: Vale Fertilizantes).

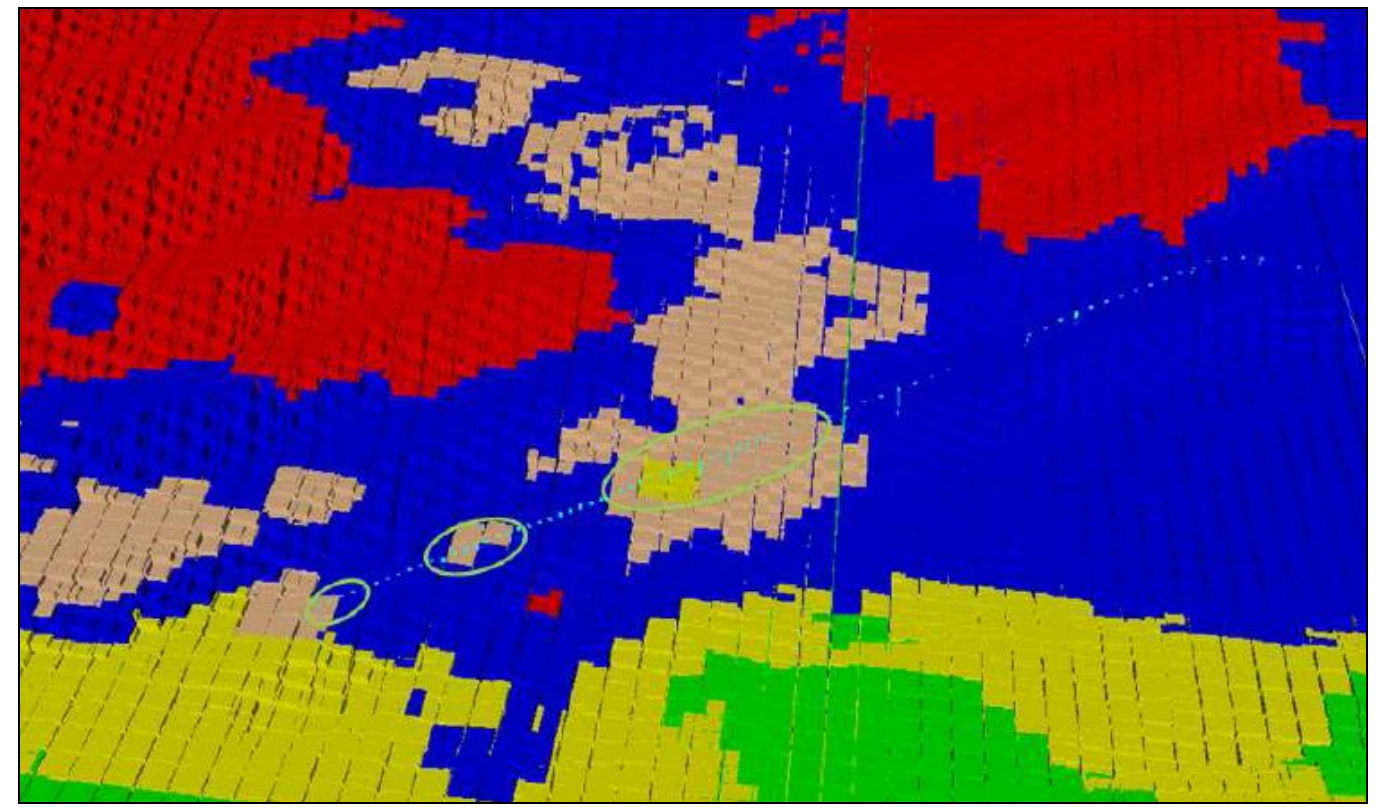

Figura 13: Ponteiras que obtiveram os melhores rendimentos de vazão (Fonte: Vale Fertilizantes).

\subsection{Minério Cimentado}

O Cimentado faz parte do domínio intempérico Isalterito. Para ser classificado desta maneira deve ter o teor de $\mathrm{P}_{2} \mathrm{O}_{5}>18 \%$. Têm em sua composição mineralógica os seguintes minerais: apatita, magnetita e silexito. 
As ponteiras que interceptaram essa tipologia apresentaram excelente rendimento de explotação de água. Devido ao alto grau de fraturamento do material, algumas ponteiras interferiam diretamente nas tubulações adjacentes. O cimentando mostrou-se ser a melhor tipologia para a execução do sistema, como pode ser visto na Figura 13, que os melhores resultados de vazão foram neste tipo de tipologia.

\subsection{Minério Oxidado e SIC B}

O Oxidado está inserido no domínio intempérico do Isalterito. Para ser classificado dessa maneira deve obedecer aos seguintes parâmetros: $\mathrm{P} 2 \mathrm{O} 5>5 \%, \mathrm{MgO}<3 \%$ e RCP entre $0.8 \%$ e 1.4\%. Seus principais minerais são apatita, magnetita, barita, quartzo e minoritariamente, vermiculita e oxi-hidróxidos de Ferro.

As ponteiras que interceptam o oxidado franco, de modo geral apresentam baixa vazão, porém o sistema consegue permitir a ascensão da água até o tubo coletor. Quando o oxidado franco está nas adjacências do domínio do cimentado, as ponteiras apresentam um rendimento mediano. Devido ao alto teor de argilo-minerais dessa tipologia a explotação de água se torna mais difícil, mesmo sendo o principal aquífero do Complexo Alcalino do Barreiro.

No controle do mapeamento de mina realizado pela geologia de curto prazo, divide-se o oxidado em dois tipos, o oxidado franco e o oxidado plástico. Esse controle foi adotado, devido a problemas de umidade excessiva presente no oxidado plástico, que prejudica a boa operação dos britadores. As ponteiras que interceptam essa tipologia não apresentam sucesso em sua grande maioria. As poucas ponteiras que retiram água do talude apresentam uma vazão baixíssima. Devido a grande presença de argilo minerais, principalmente a esmectita, a pressão negativa do sistema promove a colmatação dos filtros, impedindo o funcionamento da ponteira. Muitos furos apresentam água aflorante, porém a passagem de água até o tubo coletor não é permitida. A Figura 14 apresenta três imagens que representam os problemas relacionados a essa tipologia. 


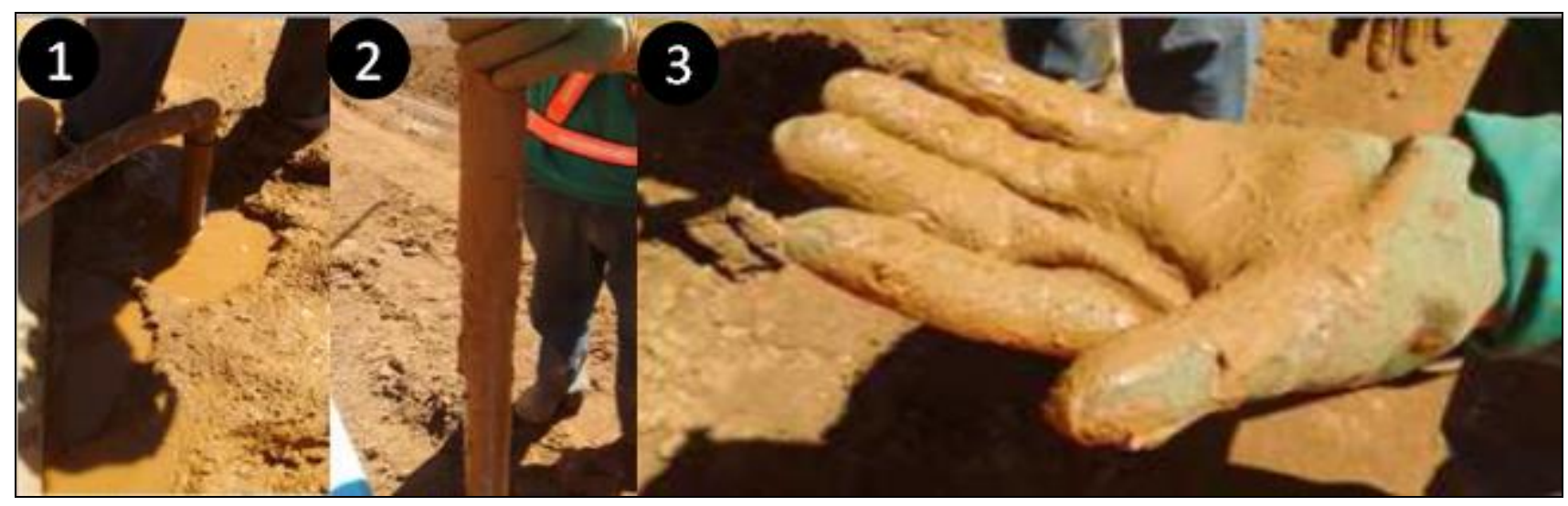

Figura 14: 1) ponteira instalada no oxidado plástico com água aflorante, porém sem sucesso na retirada de água/

2) Colmatação dos filtros/ 3) Material argiloso retirado dos filtros (Fonte: Vale Fertilizantes).

O SIC B faz parte do domínio intempérico Isalterido. Têm como premissa para sua classificação os seguintes parâmetros: $\mathrm{P}_{2} \mathrm{O}_{5}>5 \%$; $\mathrm{MgO}>3$ e RCP entre 1,4 e 1,78. Sua composição mineralógica características é a presença dos seguintes minerais: apatita, micas, magnetita, barita, anfibólio, piroxênio e esmectita.

Apenas 6 ponteiras interceptaram essa tipologia, porém em um nível superficial de 4 metros. Os 5 metros finais interceptaram uma massa de cimentado. Por essa razão tiveram um bom rendimento de vazão. Acredita-se que essa tipologia possui piores características de permeabilidade do que o oxidado franco. A Figura 15 demonstra a disposição das ponteiras em relação à vazão.

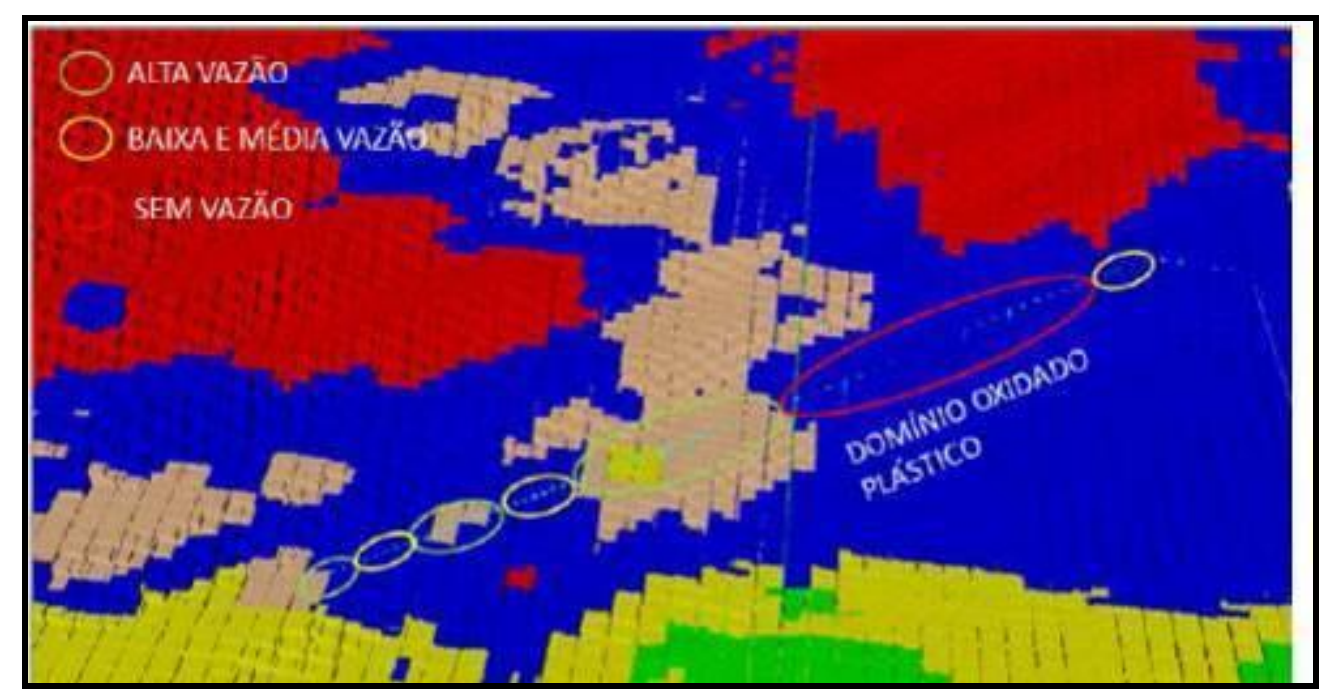

Figura 15: Ponteiras classificadas quanto à vazão característica (Fonte: Vale Fertilizantes). 


\section{CONDIÇÕES OPERACIONAIS}

\subsection{Umidade do minério}

Foram escolhidos 3 pontos para o acompanhamento dos valores da umidade. A Figura 16 apresenta a localização desses pontos.

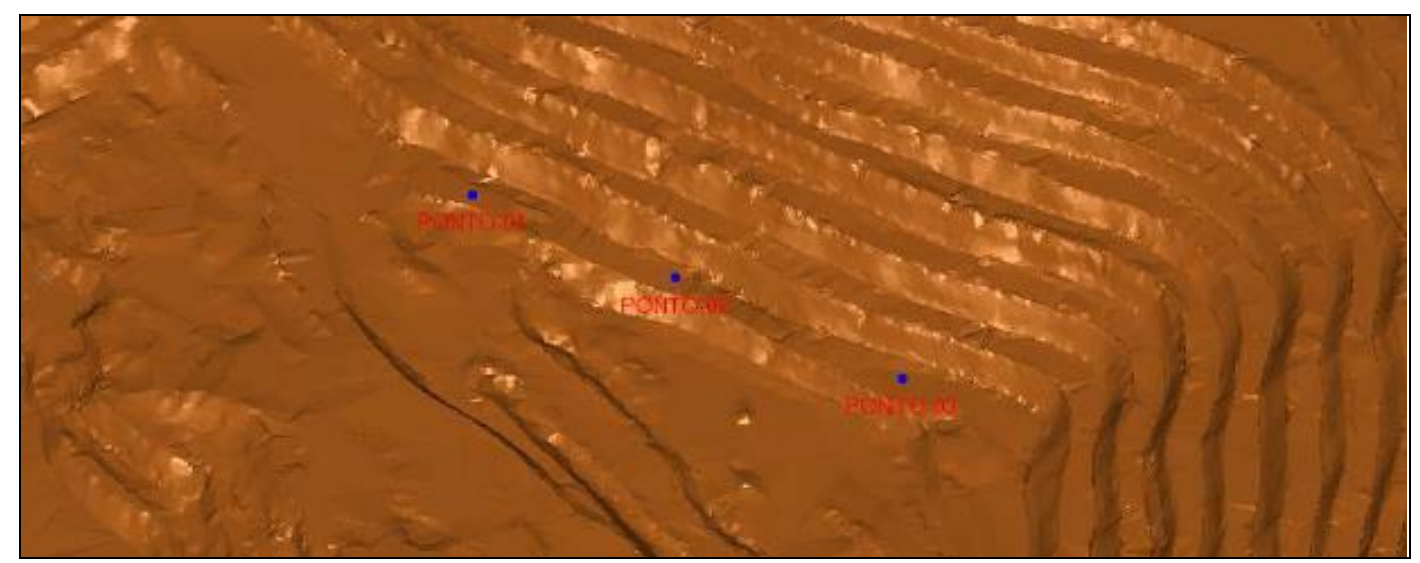

Figura 16: Localização dos pontos escolhidos para acompanhamento da umidade (Fonte: Vale Fertilizantes).

A Figura 17 mostra de modo simplificado os valores da umidade, e algumas informações a respeito do funcionamento do sistema.

\begin{tabular}{|c|c|c|c|c|c|c|c|}
\hline & & $\begin{array}{l}\text { Inicio } \\
\text { no dia }\end{array}$ & $\begin{array}{l}\text { Operação } \\
8 / 04 / 2016\end{array}$ & $\begin{array}{l}\text { Quebra d } \\
\text { no dia } 15\end{array}$ & $\begin{array}{l}\text { do sistema } \\
5 / 04 / 2016\end{array}$ & & \\
\hline & & & $\begin{array}{l}\text { SISTEMA OPE } \\
\text { DURANTE }\end{array}$ & $\begin{array}{l}\text { ERANDO } \\
5 \text { DIAS }\end{array}$ & $\begin{array}{r}\text { SISTEMA DE } \\
\text { DURANTE }\end{array}$ & $\begin{array}{l}\text { SLIGADO } \\
5 \text { DIAS }\end{array}$ & \\
\hline AMOSTRAS & INÍCıO & FIM & $\begin{array}{c}\text { DATA DE } \\
\text { AMOSTRAGEM }\end{array}$ & UMIDADE1 & $\begin{array}{c}\text { DATA DE } \\
\text { AMOSTRAGEM }\end{array}$ & UMIDADE2 & VARIAÇÃO \\
\hline PONTO-01 AMOSTRA-01-01 & 0 & 3 & $13 / 04 / 2016$ & $13.90 \%$ & $20 / 04 / 2016$ & $16.20 \%$ & $2.30 \%$ \\
\hline PONTO-01 AMOSTRA-01-02 & 3 & 6 & $13 / 04 / 2016$ & $27.00 \%$ & $20 / 04 / 2016$ & $14.20 \%$ & $-12.80 \%$ \\
\hline PONTO-01 AMOSTRA-01-03 & 6 & 9 & $13 / 04 / 2016$ & $32.60 \%$ & $20 / 04 / 2016$ & $22.90 \%$ & $-9.70 \%$ \\
\hline PONTO-02 AMOSTRA-02-01 & 0 & 3 & $13 / 04 / 2016$ & $17.40 \%$ & $20 / 04 / 2016$ & $18.30 \%$ & $0.90 \%$ \\
\hline PONTO-02 AMOSTRA-02-02 & 3 & 6 & $13 / 04 / 2016$ & $23.00 \%$ & $20 / 04 / 2016$ & SEM RECUP. & - \\
\hline PONTO-02 AMOSTRA-02-03 & 6 & 9 & $13 / 04 / 2016$ & $33.30 \%$ & $20 / 04 / 2016$ & SEM RECUP. & - \\
\hline PONTO-03 AMOSTRA-03-01 & 0 & 3 & $13 / 04 / 2016$ & $20.70 \%$ & $20 / 04 / 2016$ & $22.70 \%$ & $2.00 \%$ \\
\hline PONTO-03 AMOSTRA-03-02 & 3 & 6 & $13 / 04 / 2016$ & $14.80 \%$ & $20 / 04 / 2016$ & $18.30 \%$ & $3.50 \%$ \\
\hline
\end{tabular}

Figura 17: Esquema simplificando dos valores de umidade (Fonte: Vale Fertilizantes). 
Devido à interrupção precoce do sistema de bombeamento aliado com os problemas de recuperação do material, durante a amostragem, não se pode fazer conclusões assertivas quanto à diminuição da umidade no material, porém os valores servem como base para que se tenha um background de valores de umidade para um talude com problemas operacionais causados pelo nível de água aflorante.

Algumas considerações podem ser feitas após o entendimento da Figura 17. O PONTO-01 é o mais didático e demonstra como as ponteiras, em locais favoráveis, podem promover uma diminuição local de umidade satisfatória. Mesmo após o desligamento do sistema, o teor de umidade diminuiu em $12.8 \%$ e 9.7\% na AMOSTRA-01-02 e AMOSTRA-01-03 respectivamente. Nota-se que a AMOSTRA-01-01, mais superficial, a umidade elevou 2.3\%, o que pode ser explicado pela influência das drenagens superficiais do talude 1020 e a paralisação do sistema.

O PONTO-02 serve apenas para criar o valor de background da umidade na tipologia do cimentado. Não houve recuperação de material na AMOSTRA-02-02 e AMOSTRA-02-03 no dia 20/04/2016, por essa razão a comparação dos valores com a primeira amostragem não foi possível. Chama a atenção a AMOSTRA-02-03, que apresenta o maior valor de umidade no valor de 33\%. O aumento de 0.9\% na AMOSTRA-02-01 deve-se pelo desligamento do sistema e a influencia das drenagens do talude 1020.

O PONTO-03 está inserido no domínio do oxidado franco, porém próximo ao contato com o oxidado plástico. As ponteiras apresentaram baixa e média vazão, como mostrado na Figura 15. Após a interrupção do sistema os valores de umidade aumentaram 2\% e 3.5\%.

\subsection{Complicações operacionais}

Toda a operação de lavra de minério e estéril do Complexo Mineroquímico de Araxá está concentrada na região denominada Morro da Oficina. Devido a detonações diárias e pela fragilidade do sistema, não foi possível a manutenção das ponteiras drenantes por mais de uma semana. Foram danificados 24 metros de tubulação coletora, devido a materiais oriundos da detonação que ocorreu no dia 15/05/2016. Alguns objetivos pretendidos não foram alcançados devido à interrupção do teste.

Caso o uso desta metodologia se torne constante é necessário um planejamento refinado em parceria com a operação de mina e planejamento de mina. A bancada onde serão instaladas as ponteiras, deve ser interditada para equipamentos pesados, permitindo a passagem apenas de 
caminhonetes e caminhões munk. Na locação é necessário levar em consideração a intensidade das detonações na região, a fim de planejar a retirada do sistema de bombeamento e a proteção de todo o sistema operante.

Uma equipe especifica da infraestrutura de mina deve ser designada para a supervisão diária do sistema, analisando quais ponteiras devem ser desativadas/fechadas, a fim de se manter o sistema o mais estanque possível. Essa mesma equipe pode ser responsável por supervisionar o abastecimento do tanque externo de 1000 Litros. Devido ao caráter econômico do sistema de bombeamento, a operação de abastecimento deve ocorrer, em média, a cada 9 dias de bombeamento contínuo.

É necessário que todos os empregados que trabalhem na mina, passem por um treinamento para entendimento do sistema, visando à manutenção e melhor operação do mesmo. A implementação do gerenciamento da mudança (GM) é essencial. Com o envolvimento de todos os colaboradores, as complicações operacionais podem ser facilmente resolvidas.

\section{RECOMENDAÇÕES}

É necessário que o sistema receba adequações para que se viabilizem o sistema dentro de um ambiente dinâmico de mina:

- Para evitar a colmatação das ponteiras instaladas em litologias mais argilosas, será necessário à utilização de bidim e pré-filtro com areia selecionada entre a ponteira drenante e o diâmetro da perfuração;

- Recomenda-se uma menor metragem de sistema. Para maior mobilidade operacional a metragem entre 50 e 100 metros de tubos coletores é o mais indicado. Nesse aspecto, deverão ser priorizados os avanços de lavra mais problemáticos;

- Recomenda-se a troca dos tubos coletores de PVC por tubulações de ferro, PEAD ou de borracha, a fim de suportar fragmentos de rocha oriundos de detonações;

- É necessária a troca do PVC dos conectores, por materiais de borracha;

- O sistema de bombeamento deve possuir hidrômetros mecânicos na saída da bomba de recalque para a tubulação de descarga, afim de maior controle da vazão e do volume de água explotado; 
- Recomenda-se adaptar uma proteção que cubra todo sistema. Como por exemplo o uso de tubulações de PEAD de 17", cortadas em "meia-cana" para cobrir toda a metragem dos tubos coletores;

\section{CONCLUSÕES}

Devido à realização do teste ter se restringido a apenas uma semana de bombeamento, o objetivo principal do sistema não pode ser completamente atendido. Não foi possível concluir de forma quantitativa a efetividade da diminuição dos valores da umidade, porém os dados colhidos mostram bons indicadores quanto à sua redução, e o sistema se mostrou ser promissor.

A tipologia de minério oxidado plástico apresenta baixíssima permeabilidade. Não foi possível a retirada da água, mesmo quando o nível está aflorante. A instalação de qualquer estrutura de rebaixamento (Poços, DHP's, Ponteira drenantes etc.) deve evitar essa tipologia de minério.

Não existe tecnologia desenvolvida atualmente que possibilite o desaguamento dessa tipologia, sendo necessário o desenvolvimento de nova tecnologia voltado especificamente para litotipos de baixíssimas permeabilidades.

O minério Oxidado franco permitiu explotação de água, porém com vazões visualmente baixas. Quando próximo do domínio do cimentado as vazões aumentaram consideravelmente.

A tipologia de minério denominada cimentado é a que melhor possui características de permeabilidade, com melhor resposta de vazão nas ponteiras. Os dados mostram redução efetiva nessa zona não foi possível tirar conclusões quanto à efetividade do método na tipologia SIC-B.

Mesmo promissor o sistema de ponteiras drenantes necessitaria de uma série de modificações e adaptações afim de que se torne mais resistente e que permita suportar as atividades rotineiras da mineração (detonações, transporte de máquinas pesadas, amostragem entre outros). As recomendações foram feitas no item 7 .

O sistema se mostrou muito promissor é deve ser implementado em situações de rebaixamento de n.a. local e redução da umidade em taludes. 


\section{REFERÊNCIAS BIBLIOGRÁFICAS}

Alonso, Urbano Rodriguez. Rebaixamento temporário de aquíferos. Tenogeo/Geofix, 1999.

Biondi, J. C. 2003. Processos Metalogenéticos e Depósitos Minerais Brasileiros. 477p., São Paulo: Oficina de Textos.

Equipamentos Itubombas. Disponível em: <http://itubombas.com.br>. Acesso em: 09 de julho de2016.

Silva, A.B., Marchetto, M., Souza, O.M. 1979. Geology of the Araxá (Barreiro) Carbonatite, s.n.t. $17 \mathrm{p}$.

Silva, M.V.A., Castro, S.A.B, Trindade, A.C.C., Abud, M.C., Saito, M.K., Filho, F.S. 2012. Proposta de geração de mapas potenciométricos 2D e 3D da mina F4 da Vale Fertillizantes S.A., Araxá MG. XVII Congresso Brasileiro de Águas Subterrâneas, Bonito MS. 